\title{
Erupção Bolhosa Generalizada Durante Tratamento com Vancomicina
}

\section{Generalized Bullous Eruption During Treatment with Vancomycin}

\author{
André PINHO ${ }^{1}$, José Carlos CARDOSO ${ }^{1}$ \\ Acta Med Port 2017 Jul-Aug;30(7-8):586-586 - https://doi.org/10.20344/amp.8786
}

Palavras-chave: Dermatose Linear Bolhosa por IgA/induzida quimicamente; Erupção por Medicamento/etiologia; Vancomicina/efeitos adversos

Keywords: Drug Eruptions/etiology; Linear IgA Bullous Dermatosis/chemically induced; Vancomycin/adverse effects
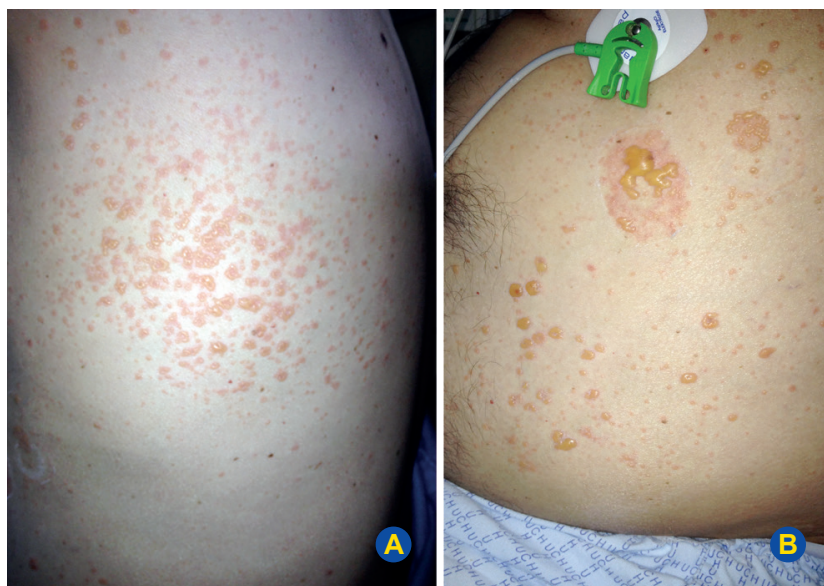

Figura 1 - Inúmeras bolhas tensas, por vezes agrupadas formando rosetas, na região torácica esquerda $(A)$. Fenómeno isomórfico com vesiculas confluentes em pele previamente traumatizada por adesivo de elétrodo cardíaco (B).

Homem de 42 anos, previamente saudável, observado por múltiplas bolhas tensas agrupadas, de conteúdo citrino, no tronco (Fig. 1A) e extremidades, sobre pele normal ou eritematosa e em locais de aplicação de adesivo (sugerindo fenómeno isomórfico) (Fig. 1B). O quadro evoluía há 10 dias, com início ao quinto dia de tratamento com vancomicina por bacteriémia por Staphylococcus aureus resistente à meticilina (SARM).

A biópsia lesional mostrou bolha subepidérmica com infiltrado rico em neutrólifos e a imunofluorescência direta perilesional evidenciou deposição linear de imunoglobulina

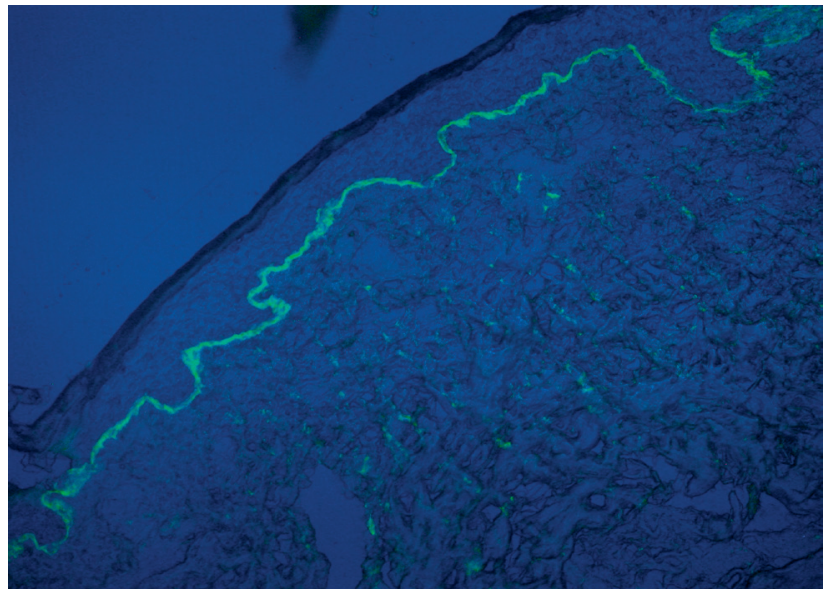

Figura 2 - Imunofluorescência direta da pele normal perilesional mostrando deposição linear de imunoglobulina $A$ ao longo da membrana basal

A ( $\lg \mathrm{A})$, ao nível da membrana basal (Fig. 2). As lesões remitiram após substituição de vancomicina por linezolido e aplicação tópica de propionato de clobetasol.

A dermatose bolhosa IgA linear é uma doença bolhosa autoimune rara, geralmente de etiologia idiopática, mas descrita em associação à administração fármacos, especialmente vancomicina. Os achados distintivos na imunofluorescência direta combinados com erupção bolhosa pós-exposição à vancomicina são suficientes para o diagnóstico, sendo recomendada interrupção do fármaco..$^{1,2}$

\section{REFERÊNCIAS}

1. Zenke $\mathrm{Y}$, Nakano T, Eto $\mathrm{H}$, Koga $\mathrm{H}$, Hashimoto T. A case of vancomycin-associated linear IgA bullous dermatosis and IgA antibodies to the a3 subunit of laminin-332. Br J Dermatol. 2014;170:965-9.

2. Ng SY, Venning VV. Management of linear IgA disease. Dermatol Clin. 2011;29:629-30.

\footnotetext{
1. Serviço de Dermatologia. Centro Hospitalar e Universitário de Coimbra Coimbra. Portugal.

$\bowtie$ Autor correspondente: André Pinho. andrecastropinho@gmail.com

Recebido: 05 de fevereiro de 2017 - Aceite: 26 de junho de 2017 | Copyright @ Ordem dos Médicos 2017
} 